\title{
Research on the Evaluation of the Efficiency of Using the Financial Funds for Tourism Poverty Alleviation: A Case Study of Guangxi Province
}

\author{
Wang Wei \\ Business School, Guilin tourism university, 26 Liangfeng Road, Yanshan District, Guilin, China
}

Keywords: Tourism poverty alleviation; Financial funds; Efficiency evaluation; Policy optimization

\begin{abstract}
The performance evaluation of tourism poverty alleviation is an important guarantee to achieve the goal of tourism poverty alleviation. The efficiency of the use of financial funds for tourism poverty alleviation projects is directly related to the overall performance of tourism poverty alleviation projects. Therefore, it is of great practical significance to construct the Guangxi tourism poverty alleviation financial fund efficiency index and quantitatively evaluate the comprehensive benefits of tourism poverty alleviation projects. The article takes Guangxi tourism poverty alleviation financial capital investment performance as the research object, based on the status quo analysis, from the completion of the tourism poverty alleviation project tasks, project management, capital management, comprehensive benefits, and tourism poverty alleviation object satisfaction and other five dimensions to construct A performance evaluation index system suitable for the actual Guangxi tourism poverty alleviation financial funds was designed, and a quantitative model was designed through the analytic hierarchy process and the efficiency coefficient method to provide a set of scientific and feasible measures for the government and relevant regulatory agencies to measure and optimize the efficiency of tourism poverty finance funds $s$ solution.
\end{abstract}

\section{Introduction}

Poverty alleviation through tourism refers to a poverty alleviation model in poverty-stricken areas rich in tourism resources through the development of tourism industry to promote local economic and social development to improve the lives of the poor and to achieve poverty alleviation[1-2]. Tourism poverty alleviation performance evaluation is an important guarantee to achieve the tourism poverty alleviation goal. Relevant scholars have conducted in-depth research from multiple perspectives, including macro, micro, positive and negative [3-5]. The significance of this study is to organically combine the performance of tourism poverty alleviation with the use of fiscal funds. The current performance evaluation of tourism poverty alleviation pays more attention to the output performance of tourism poverty alleviation, but insufficient attention to the investment performance of tourism poverty alleviation financial funds. Therefore, taking Guangxi's tourism poverty alleviation financial capital investment performance as the research object, conducting indepth research on the construction of indicator systems, indicator weight allocation, and comprehensive performance evaluation will help the government and relevant regulatory authorities understand the effectiveness of tourism poverty alleviation projects and help The measurement and evaluation of the efficiency of the use of financial resources for tourism poverty alleviation will help to propose improvement strategies for weak areas, weak projects and weak links, and then promote the dual improvement of the efficiency of the use of financial resources for tourism poverty alleviation and the performance of tourism poverty alleviation output.

\section{Analysis of the Status of Guangxi's Tourism Financial Poverty Alleviation}

\subsection{Status of Guangxi's tourism financial poverty alleviation}

According to the Guangxi financial fund information disclosure platform, Guangxi's tourism poverty alleviation financial funds are mainly invested in two ways: one is the Guangxi Tourism 
Development Special Fund, and the other is the Guangxi Zhuang Autonomous Region 's poverty alleviation special fund. The Guangxi Tourism Development Special Fund is the main channel. Since the end of 2015, Guangxi's tourism development special funds have been invested in the tourism poverty alleviation funds in four concentrated times. The approval numbers are: Gui Caixing [2015] 121, Gui Caixing [2016] 15 and Gui Caixing [2017] 33 , Guicai Bank [2018] No. 6, respectively invested RMB 68.5 million yuan, RMB 1 million yuan, RMB 6.8 million yuan and RMB 240.8 million yuan in financial funds, and a total of RMB 318.6 million yuan in financial funds (see Table 1). In addition, the Guangxi Zhuang Autonomous Region 's 2016 poverty alleviation fund allocation table shows that Daxin County of Chongzuo City received RMB 1.5 million yuan of poverty alleviation funds for the continued construction of tourism poverty alleviation points in Kanlang Village and Kantang Village.

Table 1 Structural Analysis of Guangxi's Tourism Poverty Alleviation Funds from 2016 to 2018.

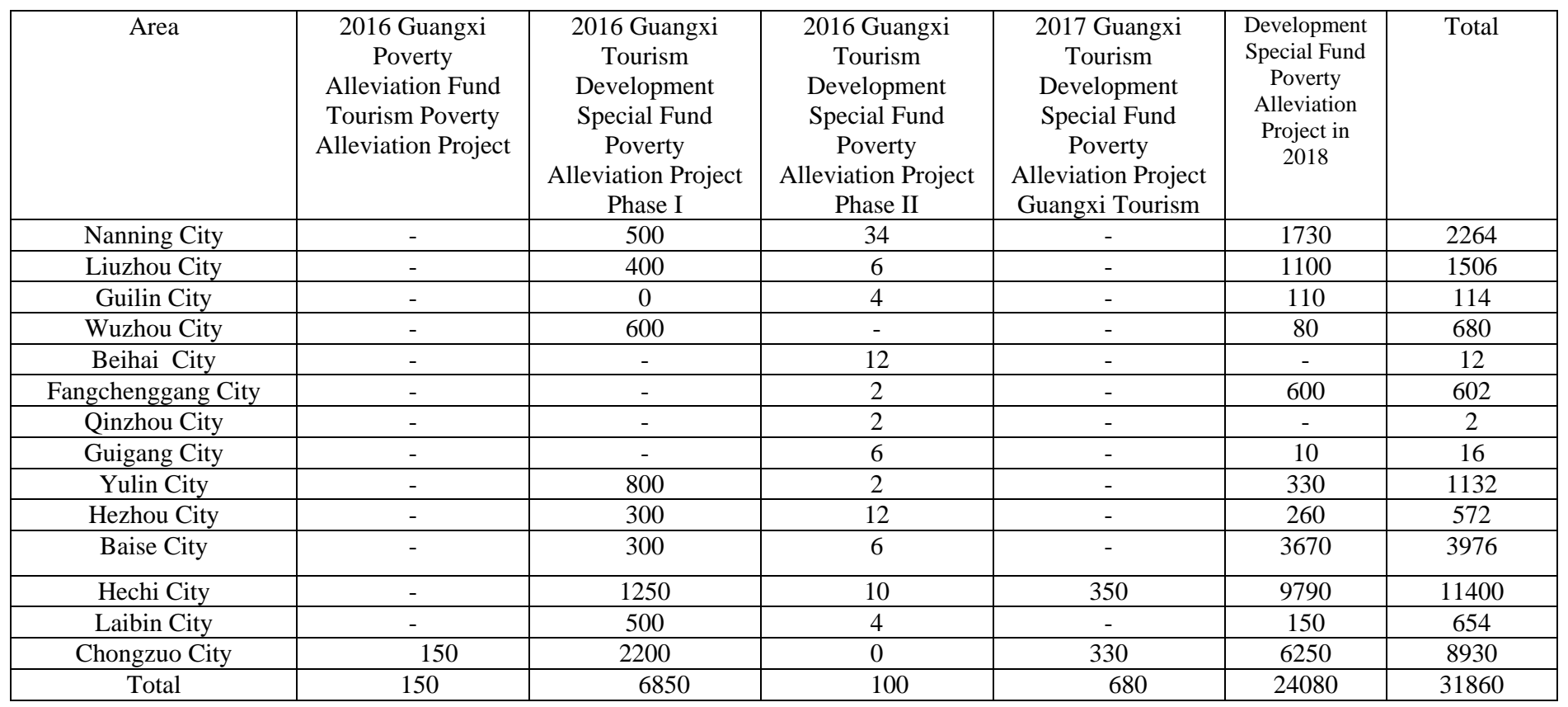

Unit: Ten Thousand Yuan

\subsection{Analysis of Guangxi's tourism financial poverty alleviation structure}

As can be seen from Table 1, the total financial investment of Guangxi's tourism poverty alleviation from 2016 to 2018 was RMB 318.6 million yuan, which showed the following characteristics: First, the annual distribution was uneven, with RMB 71 million yuan invested in 2016, only RMB 6.8 million yuan invested in 2017, and 2018 The investment was as high as RMB 240.8 million yuan. The investment in 2017 is relatively small, which may be related to the incompleteness of previous investment projects and insufficient reserve projects. Therefore, it is necessary to strengthen the reserves, research and demonstration of tourism poverty alleviation projects. The surge in inputs in 2018 shows that the party and the state have strengthened poverty reduction efforts At the same time, it also shows that tourism poverty alleviation is gaining more and more attention as an important path for poverty alleviation. At the same time, it is still necessary to emphasize the scientific nature of the earlier demonstration of tourism poverty alleviation projects, to avoid swarming when financial funds are abundant, and when financial funds are tight, urgently needed projects cannot be arranged. Secondly, the geographical distribution is uneven. The three cities of Hechi, Chongzuo and Baise have reached $76 \%$, and the total of 6 cities of Guilin, Beihai, Fangchenggang, Qinzhou, Guigang and Hezhou account for only 4\%. On the one hand, Hechi, Chongzuo, and Baise areas are underdeveloped and there are more poor counties. It is also reasonable to increase investment; on the other hand, whether there are problems such as inactive declaration and insufficient argumentation in Guilin and other 6 cities, it is also worth pondering deeply. 


\subsection{Analysis of the use of financial funds for tourism poverty alleviation in Guangxi}

Since 2016, there have been 35 projects in Guangxi that have invested more than 2 million yuan in financial funds for tourism poverty alleviation. Except for individual projects, which have been tendered through the government procurement network, the specific use of fiscal funds, expenditure details, social capital quotas, project benefits, etc. There is generally a lack of publicly disclosed information. It also creates obstacles to social supervision and may even breed corruption. Therefore, it is appealed that every project supported by financial funds, including tourism poverty alleviation projects, should regularly publicly disclose the use of financial funds and the benefits they obtain, so that the public can fully understand and exercise their right to know and monitor. At the same time, running fiscal funds in the sun will also help improve the efficiency of using fiscal funds[6].

\section{Construction of the Evaluation Index System for the Efficiency of Fiscal Funds for Tourism Poverty Alleviation in Guangxi}

\subsection{Influencing factors of the evaluation of the efficiency of financial funds for tourism poverty alleviation in Guangxi}

The evaluation of the efficiency of Guangxi's tourism poverty alleviation financial funds is mainly affected by the following factors: first, the completion of the task of tourism poverty alleviation projects, the second is the management of tourism poverty alleviation projects, the third is the management of tourism poverty alleviation funds, the fourth is the comprehensive benefits of tourism poverty alleviation, and the fifth is the target of tourism poverty alleviation Satisfaction.

\subsubsection{Completion of the tasks of tourism poverty alleviation projects}

The completion of the task of tourism poverty alleviation projects is mainly based on project declaration, project establishment, implementation and other data. Experts evaluate the implementation of the plan, the completion of core projects, and the precipitation of tangible assets after the implementation of the project. , Tangible assets precipitation rate and other indicators.

\subsubsection{Management of tourism poverty alleviation projects}

The management of tourism poverty alleviation projects mainly examines the soundness and effectiveness of the project management system and the soundness and effectiveness of the financial management system.

\subsubsection{Management of tourism poverty alleviation funds}

Management of tourism poverty alleviation funds, mainly investing in project fund input, use, supervision, and financial management, such as the availability of financial funds, the availability of self-raised funds, the consistency of project expenditures and budgets, the compliance rate of funds use, information disclosure and announcements Public information system construction and implementation[7], soundness and effectiveness of financial management system.

\subsubsection{Comprehensive benefits of tourism poverty alleviation}

The comprehensive benefits of tourism poverty alleviation mainly focus on the economic performance, ecological performance, social and cultural performance of the project. Among them, the economic benefits mainly examine the employment growth rate of tourism poverty alleviation objects, the per capita income growth rate of tourism poverty alleviation objects, the proportion of tourism income in the income of tourism poverty alleviation objects, and the driving effects of tourism poverty reduction projects on related industries. The ecological performance mainly examines the waste treatment rate, air pollution index, noise pollution index, water pollution index, forest coverage rate, negative oxygen ion content of the core scenic spots, the ratio of days with excellent air quality, surface water quality score, and clean energy. Utilization rate, toilet renovation rate, etc. Social and cultural performance mainly examines bus access rate, power supply rate, nine- 
year compulsory education rate, number of beds per 10,000 people, number of doctors per 10,000 people, gap between the rich and the poor, change rate of left-behind children's empty nest elderly, and young people returning home for employment Rate etc[8].

\subsubsection{Satisfaction of tourism poverty alleviation objects}

The satisfaction of tourism poverty alleviation objects is mainly examined whether the results of the project implementation can satisfy tourism poverty alleviation objects. Times are people who make papers, we are people who make papers, and people are people who make papers. The tourism poverty alleviation project that people are satisfied with is really a successful tourism poverty alleviation project. Satisfaction evaluation can be carried out through a questionnaire (see Table 2).

Table 2 Survey on satisfaction of tourism poverty alleviation objects.

\begin{tabular}{|c|c|c|c|c|c|c|}
\hline Dimension & Survey item & $\begin{array}{l}\text { Very } \\
\text { agree }\end{array}$ & Agree & Unclear & Against & $\begin{array}{c}\text { Very } \\
\text { opposed }\end{array}$ \\
\hline \multirow{4}{*}{$\begin{array}{l}\text { Economic } \\
\text { dimension }\end{array}$} & Promoted regional economic development & & & & & \\
\hline & Increased personal income of residents & & & & & \\
\hline & Improved residents' living standards & & & & & \\
\hline & $\begin{array}{c}\text { Wild vegetables, mountain products, and local } \\
\text { products sell better than before, with higher } \\
\text { prices }\end{array}$ & & & & & \\
\hline \multirow{9}{*}{$\begin{array}{c}\text { Social } \\
\text { dimension }\end{array}$} & Increased employment opportunities & & & & & \\
\hline & Improved residents' living ability & & & & & \\
\hline & Disturbing the daily lives of the residents & & & & & \\
\hline & Improved infrastructure & & & & & \\
\hline & Improved visibility & & & & & \\
\hline & $\begin{array}{c}\text { Promote information exchange with the outside } \\
\text { world }\end{array}$ & & & & & \\
\hline & Increased prostitution, gambling, etc. & & & & & \\
\hline & Changed traditional lifestyles and folk customs & & & & & \\
\hline & Protected local traditional culture & & & & & \\
\hline \multirow{3}{*}{$\begin{array}{l}\text { Environmental } \\
\text { dimension }\end{array}$} & Worsening environmental pollution & & & & & \\
\hline & Increased noise & & & & & \\
\hline & Improvement of living environment & & & & & \\
\hline
\end{tabular}

\subsection{Construction of guangxi tourism poverty alleviation financial fund efficiency evaluation index system based on AHP}

After the influencing factors and evaluation indicators for the efficiency of Guangxi 's tourism poverty alleviation finance funds have been determined, the key issue is how to accurately reflect the impact of various factors on the overall efficiency of tourism poverty alleviation finance funds, that is, the allocation of indicator weights. Analytic hierarchy process (AHP) is a multi-criteria decision-making method for quantitative analysis of qualitative problems. It provides mature solutions for the weight calculation of complex problems. Its characteristics divide various factors in complex problems into interconnected ordered levels, and then compare different elements of the same level in pairs based on a certain subjective judgment, and finally determine the impact weight of each element through a judgment matrix.

This article uses the expert consultation method and the analytic hierarchy process (AHP) to quantify the allocation of index weights[9]. First, the financial efficiency of tourism poverty alleviation is divided into three levels according to evaluation dimensions, influencing factors, and evaluation indicators. Second, construct a judgment matrix for each pair of comparisons. If index i is more important than index $\mathrm{j}$, then $\mathrm{a}_{\mathrm{ij}}>1$. The assignment of $\mathrm{a}_{\mathrm{ij}}$ can refer to the nine-level scale method of Satty. In order to avoid the one-sidedness of the subjective judgment of a single expert, the opinions of multiple experts should be integrated. The expert database should include leaders in the field of tourism poverty alleviation and financial systems, and theoretical and tourism experts and scholars with profound research and academic achievements. Judgment and average. Then, according to the adjusted judgment matrix, calculate its maximum eigenvalue $\lambda_{\max }$ and eigenvector $\mathrm{W}$, and normalize the eigenvector to obtain the weight corresponding to the specific index: 
$W=\left(W_{1}, W_{2}, \cdots, W_{n}\right)^{T}, W_{i}=1$. Finally, a consistency check is performed. After calculation, the index system and its weight distribution results are shown in Table 3.

Table 3 Evaluation Index System and Weighting of Guangxi's Tourism Poverty Alleviation Financial Fund Efficiency.

\begin{tabular}{|c|c|c|c|c|c|c|}
\hline Dimension & Weights & Influencing factors & Weights & Evaluation indicators & Weights & $\begin{array}{l}\text { Combined } \\
\text { weight }\end{array}$ \\
\hline \multirow{3}{*}{$\begin{array}{l}\text { A. Project task } \\
\text { completion }\end{array}$} & \multirow{3}{*}{$25 \%$} & $\begin{array}{l}\text { A1.project application } \\
\text { and implementation }\end{array}$ & $54 \%$ & $\begin{array}{c}\text { A11. Planned task completion rate (expert } \\
\text { evaluation) }\end{array}$ & $100 \%$ & $13.5 \%$ \\
\hline & & $\begin{array}{l}\text { A2.Core Project } \\
\text { Completion }\end{array}$ & $29.7 \%$ & A21 .Completion rate of core projects & $100 \%$ & $7.43 \%$ \\
\hline & & $\begin{array}{l}\text { A3.Formation of Tangible } \\
\text { Assets after Project } \\
\text { Implementation }\end{array}$ & $16.3 \%$ & A31. Precipitation rate of tangible assets & $100 \%$ & $4.08 \%$ \\
\hline \multirow{2}{*}{$\begin{array}{l}\text { B. Project } \\
\text { management }\end{array}$} & \multirow[t]{2}{*}{$16 \%$} & $\begin{array}{c}\text { B1. } \\
\begin{array}{c}\text { project management } \\
\text { system }\end{array} \\
\end{array}$ & $50 \%$ & $\begin{array}{l}\text { B11. Soundness and effectiveness of the } \\
\text { project management system (expert } \\
\text { evaluation) }\end{array}$ & $100 \%$ & $4.00 \%$ \\
\hline & & $\begin{array}{c}\text { B2. Financial } \\
\text { Management System }\end{array}$ & $50 \%$ & $\begin{array}{l}\text { B21. Soundness and effectiveness of financial } \\
\text { management system (expert evaluation) }\end{array}$ & $100 \%$ & $4.00 \%$ \\
\hline \multirow{3}{*}{$\begin{array}{l}\text { C. Fund } \\
\text { management }\end{array}$} & \multirow{3}{*}{$25 \%$} & C1. Funding & $33.3 \%$ & C11. Financial Funding Rate & $100 \%$ & $8.33 \%$ \\
\hline & & C2. Use of funds & $33.3 \%$ & C21. Fund utilization compliance rate & $100 \%$ & $8.33 \%$ \\
\hline & & C3. Fund supervision & $33.4 \%$ & $\begin{array}{l}\text { C31. Construction and implementation of } \\
\text { information disclosure and public } \\
\text { announcement system (expert evaluation) }\end{array}$ & $100 \%$ & $8.33 \%$ \\
\hline \multirow{13}{*}{$\begin{array}{l}\text { D. } \\
\text { Comprehensive } \\
\text { benefits }\end{array}$} & \multirow{13}{*}{$24 \%$} & \multirow{4}{*}{ D1. Economic benefits } & \multirow{4}{*}{$50 \%$} & D11. Employment growth rate & $25 \%$ & $3.00 \%$ \\
\hline & & & & D12. Growth rate of percapita income & $25 \%$ & $3.00 \%$ \\
\hline & & & & $\begin{array}{l}\text { D13. Proportion of tourism income to } \\
\text { residents' income }\end{array}$ & $25 \%$ & $3.00 \%$ \\
\hline & & & & $\begin{array}{l}\text { D14. Driving effects of tourism poverty } \\
\text { alleviation projects on related industries } \\
\text { (expert evaluation) }\end{array}$ & $25 \%$ & $3.00 \%$ \\
\hline & & \multirow{5}{*}{ D2. Ecological benefits } & \multirow{5}{*}{$25 \%$} & D21. Forest coverage & $20 \%$ & $1.20 \%$ \\
\hline & & & & $\begin{array}{l}\text { D22. Negative oxygen ion content in the core } \\
\text { scenic spots }\end{array}$ & $20 \%$ & $1.20 \%$ \\
\hline & & & & $\begin{array}{l}\text { D23. Ratio of days with good air quality } \\
\text { during the year }\end{array}$ & $25 \%$ & $1.50 \%$ \\
\hline & & & & D24 .Surface water quality score & $20 \%$ & $1.20 \%$ \\
\hline & & & & D25. Use of clean energy & $15 \%$ & $0.90 \%$ \\
\hline & & \multirow{4}{*}{$\begin{array}{l}\text { D3. Social and cultural } \\
\text { benefits }\end{array}$} & \multirow{4}{*}{$25 \%$} & D31. Power supply rate & $25 \%$ & $1.50 \%$ \\
\hline & & & & D32. Bus availability & $25 \%$ & $1.50 \%$ \\
\hline & & & & D33. Nine-year compulsory education rate & $25 \%$ & $1.50 \%$ \\
\hline & & & & $\begin{array}{l}\text { D34. Change rate of left-behind children's } \\
\text { empty nest elderly }\end{array}$ & $25 \%$ & $1.50 \%$ \\
\hline \multirow{3}{*}{$\begin{array}{l}\text { E. Satisfaction } \\
\text { of Tourism } \\
\text { Poverty } \\
\text { Alleviation } \\
\text { Objects }\end{array}$} & \multirow{3}{*}{$10 \%$} & E1. Economic dimension & $50 \%$ & $\begin{array}{l}\text { E11. Economic satisfaction (based on the } \\
\text { questionnaire) }\end{array}$ & $100 \%$ & $5.00 \%$ \\
\hline & & E2. Social dimension & $25 \%$ & $\begin{array}{l}\text { E22. Social satisfaction (based on the } \\
\text { questionnaire) }\end{array}$ & $100 \%$ & $2.50 \%$ \\
\hline & & $\begin{array}{l}\text { E3. Environmental } \\
\text { dimension }\end{array}$ & $25 \%$ & $\begin{array}{l}\text { E33. Environmental satisfaction (based on the } \\
\text { questionnaire) }\end{array}$ & $100 \%$ & $2.50 \%$ \\
\hline & & & Total & & & $100 \%$ \\
\hline
\end{tabular}




\subsection{The construction and measurement of the financial fund efficiency index of tourism poverty alleviation in guangxi}

Based on the evaluation index system and the weight of the financial funds for tourism poverty alleviation, the efficiency index $\mathrm{Z}$ of financial funds for tourism poverty alleviation can be constructed. The calculation formula is as follows:

$$
\mathrm{Z}=\sum_{j=1}^{n} q_{j} \times Y_{i j}
$$

Among them, $\mathrm{Z}$ is the financial fund efficiency index of tourism poverty alleviation, ${ }_{i j}$ is the single evaluation score of the $\mathrm{j}$-th index of influencing factor $\mathrm{i}$, and ${ }^{q_{j}}$ is the weight of the $\mathrm{j}$-th index. The higher the index, the higher the efficiency of the use of financial resources for tourism poverty alleviation. On the contrary, the lower the index, the lower the efficiency of the use of financial resources for tourism poverty alleviation. It is necessary to dig deeper and even initiate the accountability and punishment mechanism.

\subsubsection{Determination of evaluation scores for individual indicators}

The above indicators are mainly of two types: one is the subjective indicators that need to be evaluated by experts or measured by questionnaires, such as the completion rate of planned tasks, the soundness and effectiveness of the project management system, the soundness and effectiveness of the financial management system, Construction and implementation of information disclosure and announcement systems, economic satisfaction, social satisfaction, environmental satisfaction, etc .; the other is objective indicators that can be verified and detected based on specific data of project implementation, such as core project completion rate, tangible Asset sedimentation rate, financial capital driving rate, capital utilization compliance rate, employment growth rate, growth rate of per capita income, tourism income as a percentage of residents' income, forest coverage rate, negative oxygen ion content of core scenic spots, and days of good air quality during the year Ratio, surface water quality score, clean energy use rate, power supply rate, bus access rate, nine-year compulsory education rate, left-behind children's empty nest elderly change rate, etc. For the subjective index evaluation, the Delphi method can be used to determine the evaluation score in a percentile system. For the objective index, the efficacy coefficient method can be used in combination with historical data, objective reality, and the advanced level of similar projects to comprehensively determine the satisfaction value and disallowance of each index. Value. The specific formula is as follows:

Single indicator evaluation score $=$ (actual value-not allowed value) $/$ (satisfactory value-not allowed value) $\times 40+60$

When the actual value exceeds the optimal boundary of the satisfactory value, the single score of the indicator is 100 ; when the actual value exceeds the worst boundary of the allowed value, the single score of the indicator is 0 .

\subsubsection{Determination of the comprehensive efficiency index}

By weighting and summing up the scores of each individual indicator, the value of the efficiency index $\mathrm{Z}$ of financial funds for tourism poverty alleviation can be obtained, so as to comprehensively judge the efficiency of the use of financial funds for specific projects. As shown in Table 4. 
Table 4 Tourism Poverty Alleviation Financial Project Funding Efficiency Index Rating Table.

\begin{tabular}{|c|c|c|}
\hline $\begin{array}{l}\text { Evaluation } \\
\text { level }\end{array}$ & $\begin{array}{c}\text { Efficiency Index of } \\
\text { Tourism Poverty } \\
\text { Finance Funds }\end{array}$ & Notes on comprehensive ratings \\
\hline A & $90-100$ & $\begin{array}{l}\text { The use of fiscal funds is extremely efficient, and experience should be } \\
\text { summed up and actively promoted. }\end{array}$ \\
\hline B & $80-90$ & $\begin{array}{c}\text { The use of fiscal funds is relatively efficient, but there are still } \\
\text { shortcomings in individual links. }\end{array}$ \\
\hline $\mathrm{C}$ & $70-80$ & $\begin{array}{l}\text { The efficiency of the use of fiscal funds is average, and there are still } \\
\text { serious problems in some links. }\end{array}$ \\
\hline D & $60-70$ & $\begin{array}{l}\text { The use of fiscal funds is inefficient, and serious problems exist in } \\
\text { many links. }\end{array}$ \\
\hline E & $0-60$ & $\begin{array}{l}\text { The use of financial funds is extremely inefficient, and it is necessary } \\
\text { to dig deep into the reasons and start the accountability mechanism. }\end{array}$ \\
\hline
\end{tabular}

\section{Conclusion}

In short, to improve the efficiency of the use of financial funds for tourism poverty alleviation in Guangxi, we need to take measures to strengthen the cultivation of anti-poverty capabilities, establish and improve evaluation systems, publicize evaluation results in accordance with law, and continuously strengthen social supervision. In view of the lack of publicly available information on the current use of financial funds for tourism poverty alleviation projects in Guangxi, this study only theoretically constructed a rating system for the efficiency of the use of financial funds for tourism poverty alleviation projects in Guangxi. This is the biggest deficiency of this article, and it is also the direction for further research in the future.

\section{Acknowledgement}

This paper is the phased research results of the 2019 basic research ability improvement project of young and middle-aged teachers in Guangxi colleges and universities ( Research on the Implementation of Rural Revitalization to Solve the Imbalance and Insufficient Development of Guangxi, item No. 2019KY0838 ) and the key research project of Guilin tourism university in 2017 ( Research on risk Assessment and early warning system Construction of listed Tourism companies in ethnic areas, item No. 2017ZD06 ).

\section{References}

[1] Xing Huibin. A Review of Studies on the Theories and Methods of Performance Evaluation of Domestic Tourism Poverty Alleviation. Economic Issues, 2017 (07): 52-58.

[2] Wulan, Liu Weimin. Study on the Evaluation and Optimization of Tourism Poverty Alleviation Efficiency in Ethnic Areas of Inner Mongolia. Journal of Guangxi University for Nationalities (Philosophy and Social Science Edition), 2018, 40 (06): 21-27.

[3] Guo Lufang, Li Ruyou. Threshold Characteristics Analysis and Empirical Test of Tourism Poverty Reduction Effect: A Study Based on Chinese Provincial Panel Data. Business Economics and Management, 2016 (06): 81-91.

[4] Xiao Jianhong, Xiao Jiangnan. Research on the Poverty Alleviation Poverty-oriented Tourism Model for the Poor Based on Microeconomic Effects: A Case Study of the Ningxia Liupanshan Tourism Poverty Alleviation Experimental Area. Social Scientist, 2014 (01): 76-80.

[5] Zhang Xiaowei. The Choice and Performance Evaluation of Tourism Poverty Alleviation Mechanism in Western China. Reform and Strategy, 2016,32 (11): 101-106.

[6] Wang Chenwei, Lu Xianghu. Comparative Analysis of the Financial System of Several Major 
National New Districts Western Finance and Accounting, 2016 (10): 13-16.

[7] Li Jinlong, Liu Qiaolan. Discourse Empowerment: Policy Basis and Value Pursuit and Advancing Path to Win the Fight Against Poverty. Gansu Social Sciences, 2019 (01): 59-66.

[8] Luo Shengfeng, Huang Yanling. Performance Evaluation of Poverty Alleviation in Rocky Desertification Ecotourism Scenic Spot in Yunnan, Guizhou and Guizhou. Social Scientist, 2015 (9): 97-101.

[9] Li Lei, Zhang Guixiang. Quality of Urban Development in the Beijing-Tianjin-Hebei City Group Economic Geography, 2015,35 (05): 61-64 + 8. 